\title{
PKL electrochemical cell: physics and chemistry
}

\author{
K. A. Khan ${ }^{1} \cdot$ M. A. Mamun ${ }^{2} \cdot$ M. Ibrahim ${ }^{3} \cdot$ M. Hasan ${ }^{4} \cdot$ M. Ohiduzzaman ${ }^{5} \cdot$ A. K. M. Obaydullah ${ }^{6} \cdot$ M. A. Wadud ${ }^{7}$. \\ M. Shajahan ${ }^{2}$
}

(c) Springer Nature Switzerland AG 2019

\begin{abstract}
The efficiency of any electric cell or battery is very important. To keep it in mind, the coulombic efficiency, voltaic efficiency and energy efficiency have been studied. It was found that the coulombic efficiency data illustrated that this efficiency was higher comparing to other efficiencies may be the absence of salt bridge or separator between the electrodes. However, the highest efficiency was obtained for 40\% PKL (Pathor Kuchi Leaf) sap with 5\% secondary salt in 55\% aqueous solution, which implies that the concentration of PKL juice can play an important role regarding efficiency. It was also found that the average energy efficiency was $97.43 \%$, and it was also found that the average voltaic efficiency was $57.29 \%$. Temperature effect of the PKL electrochemical cell has also been studied. It is found that the ideal temperature for this PKL electrochemical cell is room temperature and it is from 20 to $40^{\circ} \mathrm{C}$. But, it is also usable at a lower temperature from 5 to $60^{\circ} \mathrm{C}$ as like as other standard cells. Most of the results have been tabulated and graphically discussed.
\end{abstract}

Keywords Biomass energy · Renewable energy · Electrolysis · Electric power generation

\section{Introduction}

PKL energy is a growing renewable energy technology that is built upon the expertise of several scientific disciplines. Researchers who work in PKL power design, operation and maintenance must understand the various disciplines involved in order to meet energy production and cost reductions goals. This is equally true of professionals who are new to this new and innovative field. Energy crisis is one of the most discussed issues in today's world. Most of the countries are trying to withstand this matter by any means, but we, the people of Bangladesh, are not much aware of this issue. At present, the generation demand is nearly 10,416 MW (June, 2014), whereas only three-fourth of which is considered to be available. Only $62 \%$ of the population has access to electricity with a per capita availability of $321 \mathrm{kWh}$ per annum which is significantly lesser in comparison with developing countries. Due to insufficient production of electricity, according to the demand of us, the city dwellers are suffering from load-shading in pick hours even in off-pick hours. The problem of load-shading is getting more serious because of over dependency on fossil fuel. The world reserve of natural gas is limited, and it is alarming that natural resources are about to diminish in this century. However, nuclear energy will be alternative source, but it has some major drawbacks. Burning fossil fuels cause emission of greenhouse gases (GHGs) which in turn cause global warming and pollute environment. We have to take into account that our population grows enormously and the use of energy is still significantly growing.

\footnotetext{
$\triangle$ K. A. Khan, kakhan01@yahoo.com; M. A. Mamun, zithrox@gmail.com; M. Ibrahim, mikhanjnu@gmail.com; M. Hasan, mehedi.physics@gmail.com; M. Ohiduzzaman, ohiduzzaman027@gmail.com; A. K. M. Obaydullah, obayd77@gmail.com; M. A.Wadud,wadud_shimanta03@yahoo.com; M. Shajahan, jahanms@yahoo.com|'Department of Physics, Jagannath University, Dhaka 1100, Bangladesh. ${ }^{2}$ Department of Chemistry, Jagannath University, Dhaka 1100, Bangladesh. ${ }^{3}$ Department of Chemistry, Dhaka University, Dhaka 1100, Bangladesh. ${ }^{4}$ Department of Electrical and Electronic Engineering, City University, Dhaka, Bangladesh. ${ }^{5}$ Department of Physics, Jessore University of Science and Technology, Jesssore 7408, Bangladesh. ${ }^{6}$ Instructor, URC, Ministry of Primary and Mass Education, Dhaka, Bangladesh. ${ }^{7}$ Department of Chemistry, Univercity of Rajshahi, Rajshahi, Bangladesh.
} 
The energy crisis will be a serious problem in future. So, we should think of suitable alternative. To fulfill the omnipresent demand of electricity, green energy would be the most suitable one. For primary cell, we can calculate the cell efficiency by the following three ways. These are the voltaic efficiency, the coulombic efficiency and the energy efficiency [1-5]. It was taken six cells for comparing the three efficiencies of the PKL (Pathor Kuchi Leaf) cell. The efficiencies were measured by using calibrated multi-meters. The data were recorded very carefully and graphically discussed.

\section{Mathematical models}

\subsection{Theory of voltaic efficiency}

The efficiency of an entity in electronics and electrical engineering is defined as useful power output divided by the total electrical power consumed ( $\eta$ ) [6-9].

$\therefore$ Efficiency, $\eta=\frac{\text { Useful power output }}{\text { total power input }}$.

When a cell produces a current, the current can be used to do work - to run a motor, for instance. Thermodynamical principle can be employed to derive a relation between electrical energy and the maximum amount of work $W_{\max }$ obtainable from the cell [10-13]. The maximum amount of work obtainable from the cell is:

$W_{\max }=-n F E_{\max }$

where $n$ is the number of moles of electrons transferred and is equal to the valence of the ion participating in the cell reaction. $F$ stands for Faraday and is equal to 96500 coulombs, and $E$ is the emf of the cell [14-23].

The input work, $W_{\max }=-n F E_{\max }$

The output work $W=-n F E$

$$
\begin{aligned}
\therefore \text { Efficiency }\left(\eta_{V} \%\right) & =\frac{\text { Useful power output }}{\text { Total power input }} \times 100 \% \\
& =\frac{-n F E}{-n F E_{\max }} \times 100 \%=\frac{E}{E_{\max }} \times 100 \%
\end{aligned}
$$

Here, $E_{\max }=$ cell potential without load and $E=$ load potential [24-34]

\subsection{Methodology}

The PKL was collected from the PKL tree and was blended by a blender machine for electricity production. The converter was taken as $\mathrm{Zn} / \mathrm{Cu}=1: 1$. After filtration, the different concentrations $(\mathrm{g} / \mathrm{L}$ ) of PKL extract were used in the converter for power production [35-38].

\subsection{Experimental setup}

The weight of the anode used was measured $\left(W_{1}\right)$ first, the PKL module was then prepared, and the external connection is used with an ammeter, and simultaneously, the stopwatch was started [39, 40]. The current flow was measured with a time interval so that the fluctuation of current is not so considerable, and this flow was recorded. When the cell becomes dead, then the ammeter and the stopwatch were stopped [41-51]. The metals used as anode will be separated, cleaned with distilled water and dried. The weight of the dried metal plate was measured $\left(W_{2}\right)$.

\subsection{Results and discussion}

Tables 1, 2, 3, 4 and 5 represent the voltaic efficiency $\eta_{V}$ (\%) and the average voltaic efficiency $\eta_{V}(\%)$ variation with time [45]. Voltaic efficiency for many cells were performed and observed at different compositions of solution fuelled in the cells. The potential is the important electrochemical parameter by which the work efficiency of an engine can be measured. So, the voltaic efficiency is very important parameter [52].

The change of voltaic efficiency with time is shown in Figs. 4, 5, 6, 7, 8 and 9 for different cell [53]. Here, the voltaic efficiency of the cell decreases with time. For most of the cells, the voltaic efficiency was almost steady for a certain time period. The voltaic efficiency was the highest at initial point and was the lowest at the end. This was probably for the highest concentration of reactive species $\left(\mathrm{Cu}^{2+}\right.$ and $\left.\mathrm{H}^{+}\right)$ and the lowest concentration of product ion $\mathrm{Zn}^{2+}$ [54-57]. With time, the concentration of reactive species decreases

Table 1 Difference between electrolytic and PKL electrochemical cell

\begin{tabular}{ll}
\hline Electrolytic cell & PKL quasi-galvanic cell/voltaic cell \\
\hline It requires a source of external energy & It is a source of energy \\
It converts electrical energy into chemical energy & Converts chemical energy into bio-electrical energy \\
Has cathode as the negative electrode & Has cathode as positive electrode \\
Has anode as the positive electrode & Has anode as negative electrode \\
It involves oxidation at anode and reduction at cathode & It involves oxidation at anode and reduction at cathode
\end{tabular}


Table 2 Determination of the voltaic efficiency of cell-1

\begin{tabular}{|c|c|c|c|c|c|}
\hline $\begin{array}{l}\text { Time duration } \\
\text { (min) }\end{array}$ & $\begin{array}{l}\text { Load poten- } \\
\text { tial (V) }\end{array}$ & $\begin{array}{l}\text { Open circuit } \\
\text { voltage (V) }\end{array}$ & $\begin{array}{l}\text { Maximum } \\
\text { potential (V) }\end{array}$ & $\begin{array}{l}\text { Voltaic effi- } \\
\text { ciency } \eta_{V}(\%)\end{array}$ & $\begin{array}{l}\text { Average voltaic } \\
\text { efficiency } \eta_{V}(\%)\end{array}$ \\
\hline 00 & 5.14 & 6.12 & 6.12 & 83.99 & 50.68 \\
\hline 20 & 4.70 & 6.02 & " & 76.80 & \\
\hline 40 & 3.40 & 5.20 & " & 55.55 & \\
\hline 50 & 3.12 & 4.60 & " & 50.98 & \\
\hline 60 & 2.90 & 4.30 & " & 47.39 & \\
\hline 100 & 2.70 & 3.68 & " & 44.12 & \\
\hline 140 & 2.63 & 3.32 & $"$ & 42.97 & \\
\hline 158 & 2.60 & 3.26 & " & 42.48 & \\
\hline 220 & 2.57 & 3.10 & " & 42.00 & \\
\hline 365 & 2.57 & 3.10 & " & 42.00 & \\
\hline 389 & 2.56 & 3.05 & " & 41.83 & \\
\hline 425 & 2.50 & 3.05 & " & 40.85 & \\
\hline 495 & 2.54 & 3.00 & " & 41.50 & \\
\hline 560 & 2.54 & 3.00 & $"$ & 41.50 & \\
\hline 620 & 2.54 & 3.00 & $"$ & 41.50 & \\
\hline 2145 & 2.47 & 2.90 & " & 40.36 & \\
\hline 2972 & 2.46 & 2.90 & " & 40.20 & \\
\hline
\end{tabular}

Table 3 Determination of the voltaic efficiency of cell-3

\begin{tabular}{lllll}
\hline $\begin{array}{l}\text { Time } \\
\text { duration } \\
\text { (min) }\end{array}$ & $\begin{array}{l}\text { Potential } \\
\text { with load } \\
(\mathrm{V})\end{array}$ & $\begin{array}{l}\text { Open circuit } \\
\text { voltage }(\mathrm{V})\end{array}$ & $\begin{array}{l}\text { Maximum } \\
\text { potential } \\
(\mathrm{V})\end{array}$ & $\begin{array}{l}\text { Voltaic } \\
\text { efficiency, } \\
\eta_{\mathrm{V}}(\%)\end{array}$ \\
\hline 00 & 2.58 & 4.93 & 4.93 & 52.33 \\
10 & 2.54 & 4.61 & $"$ & 51.52 \\
20 & 2.50 & 4.21 & $"$ & 50.71 \\
32 & 2.49 & 4.00 & $"$ & 50.51 \\
45 & 2.48 & 3.90 & $"$ & 50.30 \\
58 & 2.47 & 3.80 & $\prime$ & 50.10 \\
115 & 2.47 & 3.75 & $\prime$ & 50.10 \\
165 & 2.47 & 3.75 & $"$ & 50.10 \\
187 & 2.47 & 3.75 & $"$ & 50.10 \\
245 & 2.47 & 3.75 & $"$ & 50.10 \\
305 & 2.47 & 3.70 & $"$ & 50.10 \\
365 & 2.47 & 3.70 & $\prime$ & 50.10 \\
445 & 2.47 & 3.70 & $\prime$ & 50.10 \\
515 & 2.46 & 2.90 & $"$ & 49.90 \\
2788 & 2.46 & 2.90 & $"$ & 49.90 \\
\hline
\end{tabular}

and the concentration of product ion increase as a result the potential decreases and thus the voltaic efficiency decreases [58-62]. It was observed that the potential at $0 \%$ PKL was 55.36 and that for 40,50 and $60 \%$ of PKL was $50.68,52.44$ and 59.37, respectively. The cell- 6 was constructed by the anode which was plated by zinc on iron sheet (MS) and in this case the potential efficiency for the same composition of solution of other cell was lower than this cell [32-36]. Thus, by modifying the anode by plating, the voltaic efficiency can be increased. When the plating was done on MS sheet by zinc, then the zinc on the plate may slowly corrode and thus the concentration of product ion does not drop quickly and thus the voltaic efficiency becomes steady for a time period [49].

\subsection{Determination of coulombic efficiency $\eta_{Q}(\%)$}

\subsubsection{Mathematical models}

The coulombic efficiency is the ratio of the charge obtained to the total charge (charge obtained + charge lost by local action) supplied by the anode, i.e.,

$\eta_{\mathrm{Q}} \%=\frac{Q_{\text {output }}}{Q_{\text {input }}} \times 100 \%=\frac{Q_{\text {obtained }}}{Q_{\text {supplied }}} \times 100 \%$

If the lifetime of the cell becomes $t$, with an outer circuit connection, the current measured by the ammeter is $I$.

Then, the output charge

$Q_{\text {output }}=/ t$

The source of electron is the anode where electron produced by the oxidation reaction on the metal is used as anode [50]. Thus, with reaction, the weight of the anode reduces with time. If the weight of the anode used is $=W 1$, the weight after time $t$ is $=W 2$. The weight lost $=W 1-W 2=x \mathrm{~g}$. Again, the molecular weight of the metal used as anode is $M$, and the oxidation number is $n$. Then, the reaction taking place on the anode can be represented as: $A \rightarrow \mathrm{An}^{+}+n e^{-}$, where $A$ represents anode. 
Table 4 Determination of the voltaic efficiency of cell-4

\begin{tabular}{|c|c|c|c|c|c|}
\hline $\begin{array}{l}\text { Time duration } \\
\text { (min) }\end{array}$ & $\begin{array}{l}\text { Load poten- } \\
\text { tial (V) }\end{array}$ & $\begin{array}{l}\text { Open circuit } \\
\text { voltage (V) }\end{array}$ & $\begin{array}{l}\text { Maximum } \\
\text { potential (V) }\end{array}$ & $\begin{array}{l}\text { Voltaic effi- } \\
\text { ciency, } \eta_{\mathrm{V}}(\%)\end{array}$ & $\begin{array}{l}\text { Average voltaic } \\
\text { efficiency, } \eta_{\mathrm{V}} \\
(\%)\end{array}$ \\
\hline 00 & 5.60 & 6.25 & 6.25 & 89.60 & 55.36 \\
\hline 15 & 5.28 & 6.00 & " & 84.48 & \\
\hline 35 & 4.17 & 5.95 & " & 66.72 & \\
\hline 65 & 2.60 & 4.10 & $"$ & 41.60 & \\
\hline 80 & 2.60 & 3.70 & $"$ & 41.60 & \\
\hline 105 & 2.57 & 3.25 & " & 41.12 & \\
\hline 171 & 2.54 & 3.15 & " & 40.64 & \\
\hline 245 & 2.49 & 3.15 & " & 39.84 & \\
\hline 1755 & 2.46 & 3.00 & " & 39.36 & \\
\hline 2615 & 2.45 & 2.90 & $"$ & 39.20 & \\
\hline 3377 & 2.44 & 2.90 & " & 39.04 & \\
\hline
\end{tabular}

Table 5 Determination of the voltaic efficiency of cell-5

\begin{tabular}{llllll}
\hline $\begin{array}{l}\text { Time duration } \\
(\mathrm{min})\end{array}$ & $\begin{array}{l}\text { Potential with } \\
\text { load }(\mathrm{V})\end{array}$ & $\begin{array}{l}\text { Open circuit } \\
\text { voltage }(\mathrm{V})\end{array}$ & $\begin{array}{l}\text { Maximum } \\
\text { potential }(\mathrm{V})\end{array}$ & $\begin{array}{l}\text { Voltaic effi- } \\
\text { ciency, } \eta_{\mathrm{V}}(\%)\end{array}$ & $\begin{array}{l}\text { Average voltaic } \\
\text { efficiency } \eta_{\mathrm{V}}(\%)\end{array}$ \\
\hline 00 & 5.40 & 6.34 & 6.34 & 85.17 & 52.44 \\
30 & 4.76 & 5.77 & $"$ & 75.08 & \\
40 & 4.64 & 4.54 & $"$ & 73.19 & \\
55 & 2.88 & 4.45 & $"$ & 45.43 & \\
115 & 2.63 & 3.45 & $"$ & 41.48 & \\
125 & 2.60 & 3.40 & $"$ & 41.00 & \\
1125 & 2.54 & 3.00 & $\prime$ & 40.06 & \\
1185 & 2.56 & 2.80 & $"$ & 40.38 & \\
1250 & 2.54 & 2.80 & $"$ & 40.06 & \\
1310 & 2.53 & 2.82 & $\prime$ & 39.90 & \\
1405 & 2.50 & 2.71 & $\prime$ & 39.43 & \\
1475 & 2.47 & 2.65 & $\prime$ &
\end{tabular}

Thus, one mole metal will produce $\mathrm{n}$ mole electron. So, $M \mathrm{gm}$ metal anode (A) will supply $n$ mole electron. $x \mathrm{gm}$ metal anode will supply $=\frac{n \cdot x}{M}$ mole electron $=\frac{n \cdot x \cdot N_{A}}{M}$ electron $=\frac{n \cdot x \cdot N_{A} \cdot 1.6 \times 10^{-19}}{M}$ coulomb charge $=\frac{n \times F}{M}$ coulomb charge [where $F=1$ Faraday].That is, $x$ gm anode by decaying under oxidation process supply $\frac{n \times F}{M}$ coul charge. So, the input charges,

$Q_{\text {input }}=\frac{n x F}{M}$ coul charge

From (4), (5) and (6), we get, $\eta_{\mathrm{Q}} \%=\frac{Q_{\text {output }}}{Q_{\text {input }}} \times 100 \%=$ $\frac{I t}{\frac{n \times F}{M}} \times 100 \%=\frac{I t M}{n F x} \times 100 \%$

So, $\eta_{\mathrm{Q}} \%=\frac{I t M}{n F x} \times 100 \%$
By putting the values of the quantities in Eq. (7), we can calculate the coulombic efficiency.

\subsubsection{Experimental data}

See Figs. $11,12,13,14,15$ and 16

\subsubsection{Calculations of coulombic efficiency, $\eta_{Q}(\%)$ for Cell-1}

Total weight of 18 zinc plates for the construction of cell is [38] $=588.63 \mathrm{~g}$, and that after dead of cell $=562.63 \mathrm{~g}$. So, the weight lost by the zinc plates $=26.00 \mathrm{~g}$. The reaction taking place on anode (zinc plates):

$\begin{array}{lll}\mathrm{Zn} & -2 e^{-} \\ 1 \mathrm{~mol} & 2 \mathrm{~mol}\end{array} \quad \begin{aligned} & \mathrm{Zn}^{2+} \\ & 1 \mathrm{~mol}\end{aligned}$ 

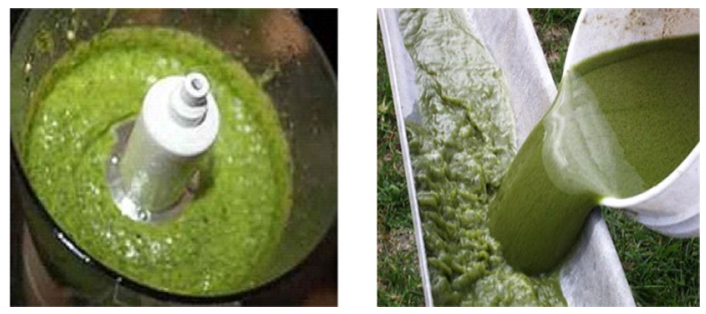

Fig. 1 Experimental setup of PKL juice making device
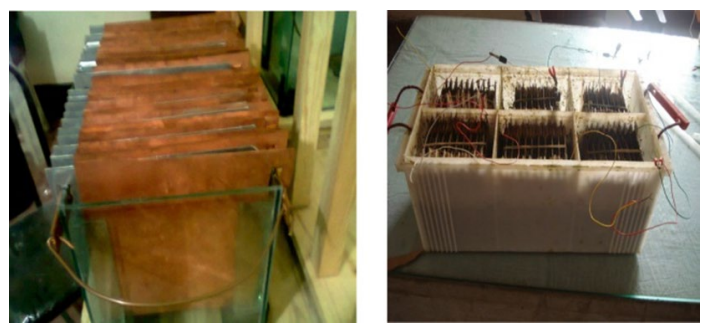

Fig. 2 Different Zn/Cu-PKL modules before putting PKL extract
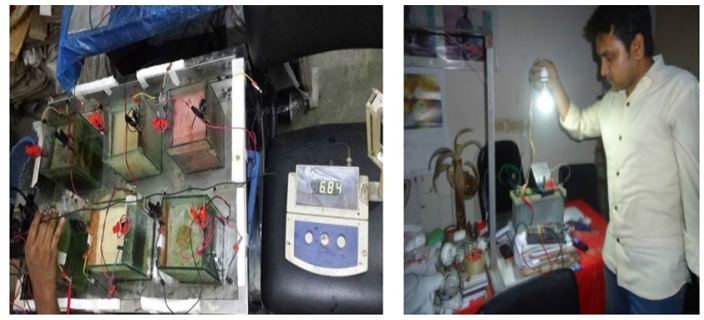

Fig. 3 Different Zn/Cu-PKL modules after putting PKL extract

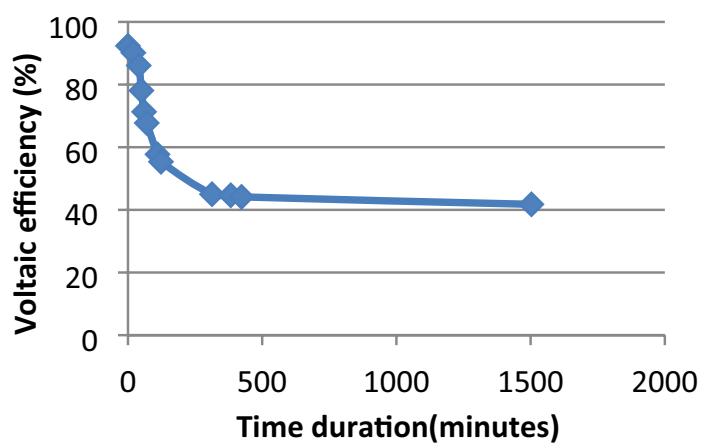

Fig. 4 Variation of voltaic efficiency with time duration for cell-1

Thus, $65.4 \mathrm{~g}$ zinc produces total of charge $=2 F=$ $193,000 \mathrm{C}$. So that, $26.00 \mathrm{~g}$ zinc produces total of charge $=$ $(193000 \times 26.00) / 65.4=76,727.83$ Coul.

Thus, the input charge $\left(Q_{\text {in }}\right)=76,727.83 \mathrm{C}$ and the output charge $\left(Q_{\text {out }}\right)=4188.97 C$. So, the coulombic

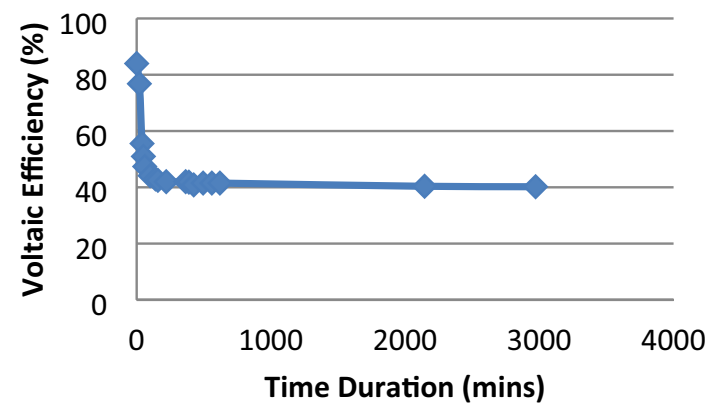

Fig. 5 Variation of voltaic efficiency with time duration for cell-2

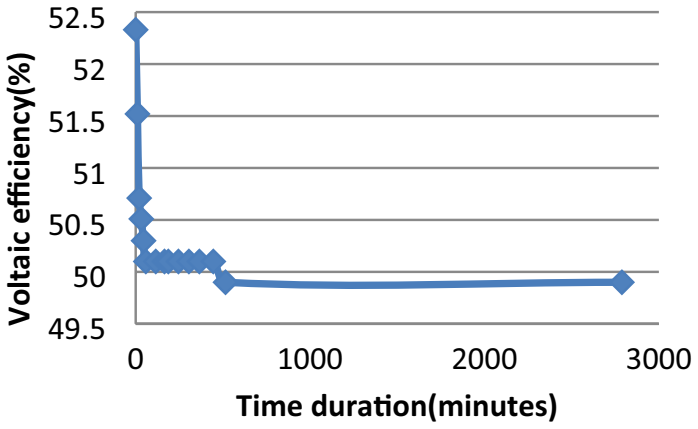

Fig. 6 Variation of voltaic efficiency with time duration for cell-3

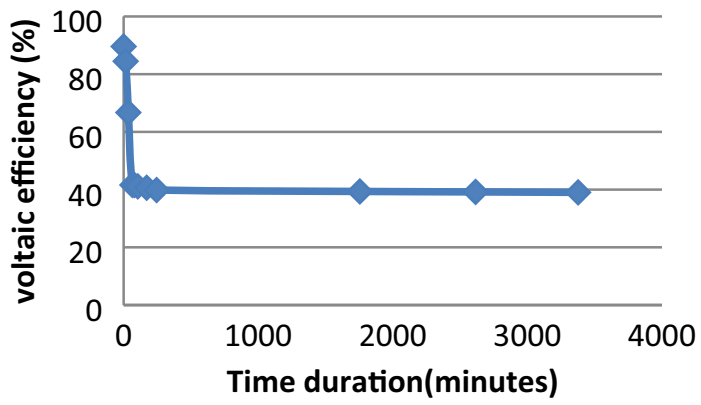

Fig. 7 Variation of voltaic efficiency with time duration for cell-4

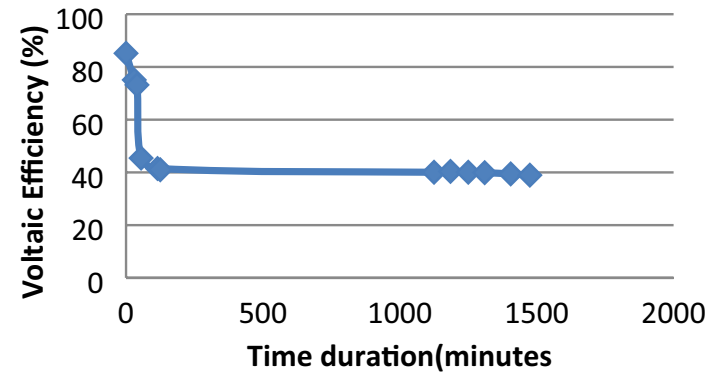

Fig. 8 Variation of voltaic efficiency with time duration for cell-5 


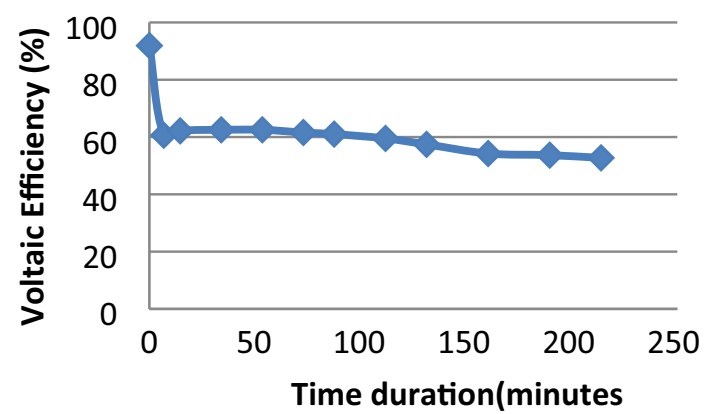

Fig. 9 Variation of voltaic efficiency with time duration for cell-6

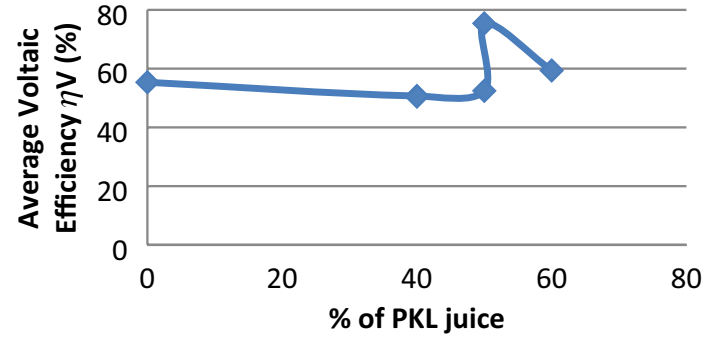

Fig. 10 Variation of voltaic efficiency with the change of \% of PKL juice/extract

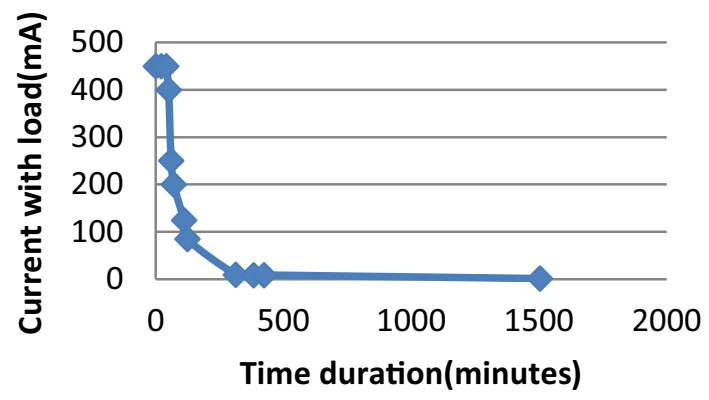

Fig. 11 Change of current with load with the time for cell-1

efficiency $=$ Output charge $/$ Input charge $=Q_{\text {out }} / Q_{\text {in }}=418$ $8.97 C / 76,727.83 C=5.46 \%$. Similarly, the coulombic efficiency for the other cells can be calculated, and the results obtained are given in the following table. The change of coulombic efficiency, $\eta_{\mathrm{Q}}(\%)$ with the change of $\% \mathrm{PKL}$ juice, is shown in Fig. 16.

\subsubsection{Difference between electrolytic and PKL quasi-galvanic/voltaic cells}

There are some fundamental distinctions between electrolytic cell and PKL electrochemical cell. These are given in the following Table 1.

\section{SN Applied Sciences}

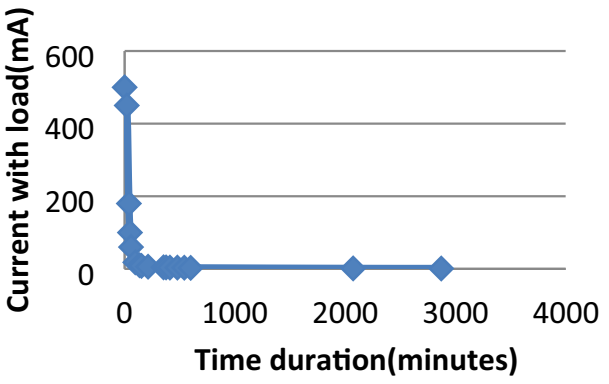

Fig. 12 Charge transfer through the circuit for cell-2

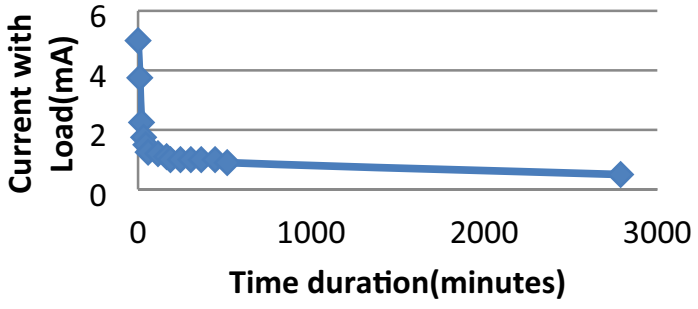

Fig. 13 Variation of current with the time for cell-3

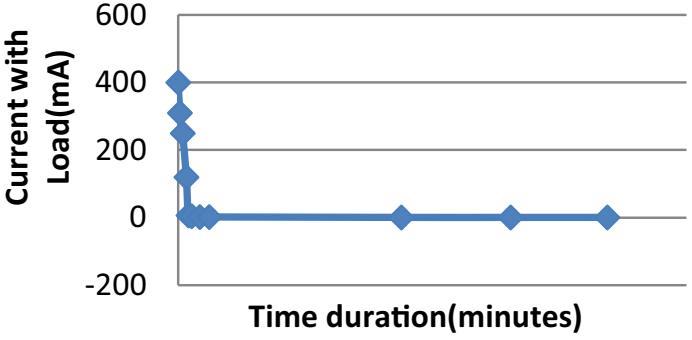

Fig. 14 Variation of current with the time for cell-4

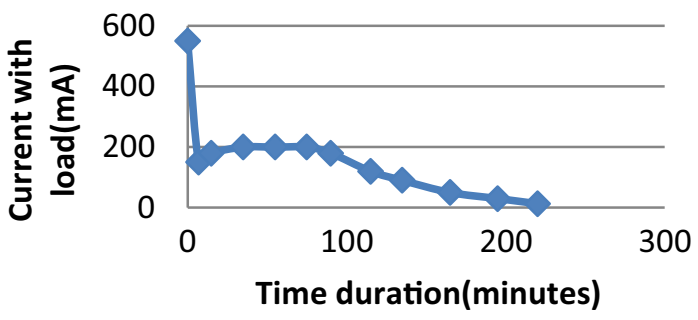

Fig. 15 Variation of current with the variation of time duration for cell-6

\subsubsection{Results and discussion}

Tables 2, 3 and 4 represent the current flow with time. Here, the current at first changes sharply and after a certain period this flow becomes steady having the low value of flow. To calculate the charge transferred through the circuit with a 3 W LED bulb, the average method was 


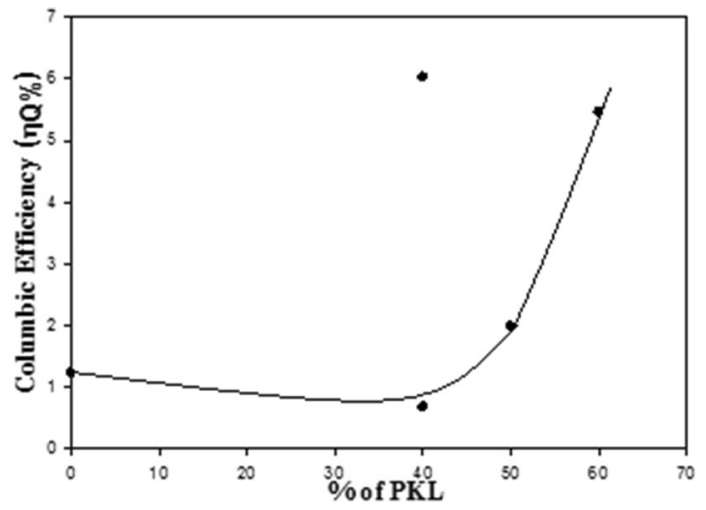

Fig. 16 Variation of coulombic efficiency $\left(\eta_{\mathrm{Q}} \%\right)$ with the variation of $\% \mathrm{PKL}$

Fig. 17 Equivalent circuit of a PKL cell
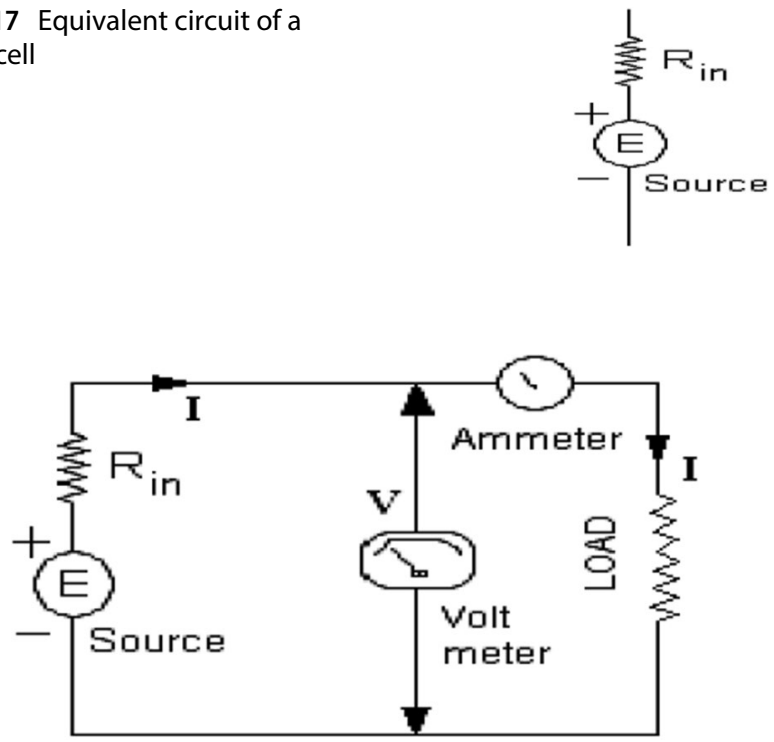

Fig. 18 Circuit arrangement for measuring power

followed. And for this, with the help of current versus time, a significant change is observed from Figs. 1, 2, 3, 4 and 5 which was marked with the sign A, B, C and D. For each portion separately, the charge transfer calculated and then added together. Table 5 and Fig. 9 both show the change of coulombic efficiency $\left(\eta_{\mathrm{Q}} \%\right)$ with the change of PKL juice [42-48]. Here, the coulombic efficiency $\left(\eta_{\mathrm{Q}} \%\right)$ was $5.46,6.02,0.68,1.23,1.98$ at $60,40,40,0,50 \%$ of PKL juice, respectively. Here, without PKL juice, the coulombic efficiency was low again without secondary salt and the coulombic efficiency became the lowest. Again for the cell- 6 where the $\%$ of PKL was $50 \%$, yet the coulombic efficiency was only $1.98 \%$. In this cell, the anode used was plated with zinc on MS sheet. Thus, it can be concluded that the anode should not be plated to get the high coulombic efficiency [24].The surface morphology was examined with the scanning electron microscopy (SEM) and found to be cubic grain with homogeneous distribution.

Figure 1 shows the experimental setup of PKL Juice making machine. Figure 2 shows the $\mathrm{Zn} / \mathrm{Cu}-\mathrm{PKL}$ Cell before putting extract. Figure 3 shows the $\mathrm{Zn} / \mathrm{Cu}$-PKL Cell after putting extract. Figure 4 shows the variation of voltaic efficiency with the variation of time for cell-1. Figure 5 shows the change of voltaic efficiency with time for cell- 2 . Figure 6 shows the change of voltaic efficiency with time for cell-3. Figure 7 shows the change of voltaic efficiency with time for cell-4. Figure 8 shows the change of voltaic efficiency with time for cell-5. Figure 9 shows the change of voltaic efficiency with time for cell-6. Figure 10 shows the change of voltaic efficiency with the change of $\%$ of PKL juice. Figure 11 shows the change of current with load with the time for cell-1. Figure 12 shows the charge transfer through the circuit for cell-2. Figure 13 shows the variation of current with the time for cell-3. Figure 14 shows the variation of current with the time for cell-4 (Figs. 15 and 16).

\subsection{Determination of energy efficiency $\eta_{E}(\%)$}

Battery is subjected to charge. A battery needs to be charged before use. During charging, it uses energy and during discharging we get energy from it. The efficiency of a battery is calculated as below:

Energy Efficiency, $\eta_{\mathrm{E}}=E_{\mathrm{D}} / E_{\mathrm{C}}$

where, $\quad E_{\mathrm{D}}=$ Energy during charging $=V_{\mathrm{D}} I_{\mathrm{D}} T_{\mathrm{D}}$

Here, $V_{D}=$ discharging voltage $(V), I_{D}=$ discharging current (A), $T_{D}=$ discharging time (h). Then, we have

$E_{C}=$ Total energy during discharging $=V_{C} I_{C} T_{C}$

Here, $V_{C}=$ charging voltage $(V), I_{C}=$ charging current $(\mathrm{A})$, $T_{\mathrm{C}}=$ charging time $(\mathrm{h})$.

Therefore, we can write,

Energy efficiency $=\frac{V_{D} I_{D} T_{D}}{V_{C} I_{C} T_{C}}$

or,

Energy efficiency $=\left(\frac{V_{D}}{V_{C}}\right)\left(\frac{I_{D} T_{D}}{I_{C} T_{C}}\right)$

or,

Energy efficiency $=\left(\frac{\text { Discharge voltage }}{\text { Charge voltage }}\right)$

$\left(\frac{\text { Discharge ampere hour }(\mathrm{AH})}{\text { Charge ampere hour }(\mathrm{AH})}\right)$ 
Table 6 Determination of the voltaic efficiency of cell- 6

\begin{tabular}{llllll}
\hline $\begin{array}{l}\text { Time duration } \\
(\mathrm{min})\end{array}$ & $\begin{array}{l}\text { Load poten- } \\
\text { tial }(\mathrm{V})\end{array}$ & $\begin{array}{l}\text { Open circuit } \\
\text { voltage }(\mathrm{V})\end{array}$ & $\begin{array}{l}\text { Maximum } \\
\text { potential }(\mathrm{V})\end{array}$ & $\begin{array}{l}\text { Voltaic effi- } \\
\text { ciency } \eta_{\mathrm{V}}(\%)\end{array}$ & $\begin{array}{l}\text { Average voltaic } \\
\text { efficiency } \eta_{\mathrm{V}}(\%)\end{array}$ \\
\hline 00 & 4.88 & 5.31 & 5.31 & 91.90 & 75.40 \\
07 & 3.22 & 3.35 & $"$ & 60.64 & \\
15 & 3.30 & 3.60 & $"$ & 62.15 & \\
35 & 3.32 & 3.65 & $"$ & 62.52 & \\
55 & 3.32 & 3.62 & $"$ & 62.52 & \\
75 & 3.27 & 3.61 & $"$ & 61.58 & \\
90 & 3.24 & 3.57 & $"$ & 61.02 & \\
115 & 3.16 & 3.52 & $"$ & 59.51 & \\
135 & 3.05 & 3.50 & $"$ & 57.44 & \\
165 & 2.88 & 3.35 & $"$ & 54.24 & \\
195 & 2.85 & 3.30 & $"$ & 53.67 & \\
220 & 2.80 & 3.00 & $"$ & 52.73 & \\
\hline
\end{tabular}

If I A current flows through the output load, this current will also flow through the internal resistance $R$ of the circuit. Now, if $V$ is the load voltage, then the output power $=V \times I$, and power loss in internal resistance $=I^{2} R$.

Therefore, we can calculate the power efficiency as

Energy efficiency $=\frac{\text { Output }}{\text { Output }+ \text { Losses }}$

The losses may include polarization, resistance (electronic conductor and electrolytic conductor), the absence of salt bridge, the presence of impurity. Considering the loss arises only in the presence of internal resistance and neglecting other losses, we get

Or,

Energy efficiency $=\frac{V \times I}{(V \times I)+I^{2} R}$

Energy efficiency is generally represented as percentage value.

Energy efficiency $=\frac{V \times I}{(V \times I)+I^{2} R} \times 100 \%$

\subsubsection{Experimental data}

The energy efficiencies for different six cells are shown in Table 14. The highest and the lowest energy efficiencies are $99.96 \%$ and $96.73 \%$, respectively (Table 14 ).

Table 7 Observation of the average voltaic efficiency, $\eta_{\mathrm{V}}(\%)$ with $\%$ of PKL juice

\begin{tabular}{lll}
\hline Cell no. & \% of PKL juice & $\begin{array}{l}\text { Average voltaic } \\
\text { efficiency } \eta_{\mathrm{V}}(\%)\end{array}$ \\
\hline 1 & 60 & 59.37 \\
2 & 40 & 50.68 \\
3 & 40 & 50.48 \\
4 & 0 & 55.36 \\
5 & 50 & 52.44 \\
6 & 50 & 75.40 \\
\hline
\end{tabular}

\subsubsection{Calculation of energy efficiency $\eta_{E}(\%)$ for cell-1}

Load voltage, $V=3.500 \mathrm{~V}$, load current, $I=0.154 \mathrm{~A}$, internal resistance, $R=0.6 \Omega$. Therefore, we can find the output power $=$ load voltage $\times$ load current $=$ $3.50 \mathrm{~V} \times 0.154 \mathrm{~A}=0.539 \mathrm{~W}$. Power loss in internal resistance of the cell $=(0.154 \mathrm{~A})^{2} \times 0.6=0.014 \mathrm{~W}$. Therefore, the Energy efficiency $=\frac{0.539}{0.539+0.014} \times 100 \%$. 
Table 8 Determination of the charge transfer through the circuit for cell-1

\begin{tabular}{|c|c|c|c|c|c|c|c|}
\hline SI no. & Sample no. & $\begin{array}{l}\text { Time duration } \\
\text { (min) }\end{array}$ & Total time $t(\mathrm{~s})$ & Load current (mA) & $\begin{array}{l}\text { Average cur- } \\
\text { rent, } I(\mathrm{~A})\end{array}$ & $\begin{array}{l}\text { Charge flowed } \\
(C=I t)\end{array}$ & $\begin{array}{l}\text { Total charge } \\
\text { transferred } \\
\text { (C) }\end{array}$ \\
\hline 01 & C1S2 & 00 & 12,000 & 450.00 & 0.301 & 3612 & 4188.97 \\
\hline 02 & C1S3 & 20 & & 450.00 & & & \\
\hline 03 & - & 40 & & 450.00 & & & \\
\hline 04 & C1S4 & 50 & & 400.00 & & & \\
\hline 05 & - & 60 & & 250.00 & & & \\
\hline 06 & C1S5 & 70 & & 200.00 & & & \\
\hline 07 & C1S6 & 110 & & 125.00 & & & \\
\hline 08 & - & 123 & & 85.00 & & & \\
\hline 09 & C1S7 & 313 & 78,180 & 10.00 & 0.00738 & 576.97 & \\
\hline 10 & C1S9 & 383 & & 9.00 & & & \\
\hline 11 & - & 423 & & 9.00 & & & \\
\hline 12 & C1S10 & 1503 & & 1.50 & & & \\
\hline
\end{tabular}

Table 9 Determination of the charge transfer through the circuit for cell-2

\begin{tabular}{|c|c|c|c|c|c|c|c|}
\hline SI no. & Sample No. & Total time (min) & Total time $t(\mathrm{~s})$ & Load current (mA) & $\begin{array}{l}\text { Average cur- } \\
\text { rent I (A) }\end{array}$ & $\begin{array}{l}\text { Charge flowed } \\
\text { (C) }[Q=I t]\end{array}$ & $\begin{array}{l}\text { Total charge } \\
\text { transferred } \\
\text { (C) }\end{array}$ \\
\hline 01 & $\mathrm{C} 2 \mathrm{~S} 2$ & 00 & 6000 & 500.00 & 0.22 & 1308 & 2055.87 \\
\hline 02 & $\mathrm{C} 2 \mathrm{S3}$ & 20 & & 450.00 & & & \\
\hline 03 & C2S4 & 40 & & 180.00 & & & \\
\hline 04 & - & 50 & & 100.00 & & & \\
\hline 05 & - & 60 & & 60.00 & & & \\
\hline 06 & C2S5 & 100 & & 18.00 & & & \\
\hline 07 & $\mathrm{C} 2 \mathrm{~S} 6$ & 140 & 172,320 & 10.00 & 0.0044 & 747.87 & \\
\hline 08 & - & 158 & & 8.25 & & & \\
\hline 09 & - & 220 & & 6.00 & & & \\
\hline 10 & $\mathrm{C} 2 \mathrm{~S} 7$ & 365 & & 4.25 & & & \\
\hline 11 & - & 389 & & 4.00 & & & \\
\hline 12 & C2S8 & 425 & & 3.50 & & & \\
\hline 13 & - & 495 & & 3.50 & & & \\
\hline 14 & - & 560 & & 3.20 & & & \\
\hline 15 & C2S9 & 620 & & 2.75 & & & \\
\hline 16 & $\mathrm{C} 2 \mathrm{~S} 10$ & 2145 & & 1.25 & & & \\
\hline 17 & - & 2972 & & 1.00 & & & \\
\hline
\end{tabular}

Or, energy efficiency $=97.43 \%$. Similarly, for another cells, the calculation was done and given above table.

\subsubsection{Temperature effect of a PKL cell}

Cell performance of a PKL battery or PKL cell changes dramatically with temperature. At the lower extreme temperature, the electrolyte itself may freeze setting a lower limit on the operating temperature. At the upper extreme temperature, the active chemicals of PKL cell may break down destroying the battery. In between these limits, the PKL cell performance generally improves with temperature.

\subsubsection{Chemical analysis}

By analyzing the experimental data obtained from AAS, UV-Vis, VOM, pH metric analysis and visual inspection of the PKL cell, we can conclude the findings as - the AAS, UV-Vis and $\mathrm{pH}$ metric analysis show that both $\mathrm{Cu}^{2+}$ and 
Table 10 Determination of the charge transfer through the circuit for cell-3

\begin{tabular}{llcllll}
\hline SI no. & Total time $(\mathrm{min})$ & Total time $t(\mathrm{~s})$ & $\begin{array}{l}\text { Load } \\
\text { current } \\
(\mathrm{mA})\end{array}$ & Average current I (A) & $\begin{array}{l}\text { Charge } \\
\text { flowed } \\
(C=I t)\end{array}$ & $\begin{array}{l}\text { Total charge } \\
\text { transferred } \\
(\mathrm{C})\end{array}$ \\
\hline 01 & 00 & 3480 & 5.00 & 0.003 & 8.98 & 167.32 \\
02 & 10 & & 3.75 & & & \\
03 & 20 & & 2.25 & & \\
04 & 32 & 1.75 & & & \\
05 & 45 & & 1.50 & & & \\
06 & 58 & 1.25 & & & \\
07 & 115 & 1638.34 & \\
08 & 165 & 1.20 & $9.67 \times 10^{-4}$ & \\
09 & 187 & & 1.10 & & & \\
10 & 245 & 1.00 & & & \\
11 & 305 & 1.00 & & & \\
12 & 365 & 1.00 & & & \\
13 & 445 & 1.00 & & & \\
14 & 515 & 1.00 & & & \\
15 & 2788 & 0.90 & & & \\
\hline
\end{tabular}

Table 11 Determination of the charge transfer through the circuit for cell-4

\begin{tabular}{llccccc}
\hline SI no. & Sample no. & $\begin{array}{l}\text { Time duration } \\
(\mathrm{min})\end{array}$ & Total time $t(\mathrm{~s})$ & $\begin{array}{l}\text { Load current } \\
(\mathrm{mA})\end{array}$ & $\begin{array}{c}\text { Average current }(\mathrm{A}) \\
\text { Charge flowed }\end{array}$ & $\begin{array}{l}\text { Transferred } \\
(\mathrm{C}=I t) \mathrm{C}\end{array}$ \\
\hline 01 & C4S2 & 00 & 4800 & 400.0 & 0.22 & 1043.52 \\
02 & C4S3 & 15 & & 310.0 & & 1349.94 \\
03 & C4S4 & 35 & & 250.0 & & \\
04 & C4S5 & 65 & 120.0 & & 306.62 \\
05 & C4S6 & 80 & & 7.0 & & \\
06 & C4S7 & 105 & 197,820 & 4.0 & $1.55 \times 10^{-3}$ & \\
07 & - & 171 & & 2.0 & & \\
08 & C4S8 & 245 & & 1.8 & & \\
09 & C4S9 & 1755 & & 0.5 & & \\
10 & - & 2615 & 3377 & 0.5 & & \\
11 & C4S10 & & 0.5 & & \\
\hline
\end{tabular}

Table 12 Determination of coulombic efficiency of different PKL cells at different compositions

\begin{tabular}{|c|c|c|c|c|c|c|c|}
\hline Cell No. & $\begin{array}{l}\text { Weight of anode } \\
\text { before using }(\mathrm{g}) \\
{\left[W_{1}\right]}\end{array}$ & $\begin{array}{l}\text { Weight of anode } \\
\text { after using }(\mathrm{g}) \\
{\left[W_{2}\right]}\end{array}$ & $\begin{array}{l}\text { Weight lost by } \\
\text { anodic process }(\mathrm{g}) \\
{\left[W_{1}-W_{2}\right]=x \mathrm{~g}}\end{array}$ & $\begin{array}{l}\text { Input charge }(C) \\
\left(\frac{2 F x}{65.4}\right)\end{array}$ & $\begin{array}{l}\text { Output charge } \\
\text { (C) }\end{array}$ & $\begin{array}{l}\text { Coulombic } \\
\text { efficiency, }\left(\eta_{\mathrm{Q}} \%\right) \\
\frac{Q_{\text {output }}}{Q_{\text {input }}} 100 \%\end{array}$ & $\begin{array}{l}\% \text { of } \mathrm{PKL} \\
\text { used in } \\
\text { solution }\end{array}$ \\
\hline 1 & 588.63 & 562.63 & 26.00 & $76,727.83$ & 4188.97 & 5.46 & 60 \\
\hline 2 & 593.43 & 581.86 & 11.57 & $34,143.88$ & 2055.88 & 6.02 & 40 \\
\hline 3 & 589.49 & 581.16 & 8.33 & $24,582.4$ & 167.32 & 0.68 & 40 \\
\hline 4 & 589.29 & 552.13 & 37.16 & $109,661.76$ & 1349.94 & 1.23 & 0 \\
\hline 6 & 771.5 & 754.15 & 27.35 & $80,711.77$ & 1601.94 & 1.98 & 50 \\
\hline
\end{tabular}


Table 13 Determination of the charge transfer through the circuit for cell-6

\begin{tabular}{|c|c|c|c|c|c|c|}
\hline SI No & $\begin{array}{l}\text { Total time } \\
\text { (min) }\end{array}$ & Total time $t(\mathrm{~s})$ & $\begin{array}{l}\text { Load current } \\
(\mathrm{mA})\end{array}$ & $\begin{array}{l}\text { Average cur- } \\
\text { rent, I (A) }\end{array}$ & $\begin{array}{l}\text { Charge flowed } \\
(C=I t)\end{array}$ & $\begin{array}{l}\text { Charge } \\
\text { transferred } \\
\text { (C) }\end{array}$ \\
\hline 01 & 00 & 420 & 550 & 0.35 & 147 & 1601.94 \\
\hline 02 & 07 & & 150 & & & \\
\hline 03 & 15 & 6480 & 180 & 0.180 & 1166.4 & \\
\hline 04 & 35 & & 200 & & & \\
\hline 05 & 55 & & 200 & & & \\
\hline 06 & 75 & & 200 & & & \\
\hline 07 & 90 & & 180 & & & \\
\hline 08 & 115 & & 120 & & & \\
\hline 09 & 135 & 6300 & 90 & 0.0458 & 288.54 & \\
\hline 10 & 165 & & 50 & & & \\
\hline 11 & 195 & & 30 & & & \\
\hline 12 & 220 & & 13 & & & \\
\hline
\end{tabular}

Table 14 The energy efficiency calculation for the internal resistance, $R=0.6 \Omega$

\begin{tabular}{lllll}
\hline Cell no. & $\begin{array}{l}\text { Internal resistance } \\
(\Omega)\end{array}$ & $\begin{array}{l}\text { Average load poten- } \\
\text { tial, } V(\mathrm{~V})\end{array}$ & $\begin{array}{l}\text { Average load current, } \\
I(\mathrm{~A})\end{array}$ & $\begin{array}{l}\text { Energy effi- } \\
\text { ciency, } \eta_{\mathrm{E}}= \\
\frac{V I}{V I+I^{2} R} \times 100 \%\end{array}$ \\
\hline 1 & 0.6 & 3.500 & 0.154 & 97.43 \\
2 & $"$ & 3.102 & 0.111 & 98.9 \\
3 & $"$ & 2.489 & $1.774 \times 10^{-3}$ & 99.96 \\
4 & $"$ & 3.271 & 0.109 & 98.4 \\
5 & $"$ & 3.358 & 0.166 & 97.12 \\
6 & $"$ & 3.404 & 0.192 & 96.73 \\
\hline
\end{tabular}

$\mathrm{H}^{+}$ions simultaneously reduce with the progress of electrochemical reaction, whereas the concentration of $\mathrm{Zn}^{2+}$ increases rapidly. Thus, we can infer that $\mathrm{H}^{+}$and $\mathrm{Cu}^{2+}$ ions behave as reactant species, i.e., act as oxidant, while $\mathrm{Zn}$ behaves as reductant species. However, the visual inspection and the reduction in weight of $Z n$ plates also strongly support that $Z n$ electrode is the main source of electron. On the other hand, from the VOM data, we can decide that the potential and current flow decrease with the decrease in the concentration of $\mathrm{H}^{+}$and $\mathrm{Cu}^{2+}$ ions in PKL juice solution. Therefore, we can propose the electrochemical reaction occurred in the PKL cell as follows:

$2 \mathrm{Zn}+\mathrm{Cu}^{2+}+2 \mathrm{H}+\rightarrow 2 \mathrm{Zn}^{2+}+\mathrm{Cu}+\mathrm{H}_{2} \uparrow$

Reaction at anode: $2 \mathrm{Zn}+4 e^{-} \rightarrow 2 \mathrm{Zn}^{2+}$

Reactions at cathode: $\mathrm{Cu}^{2+}+2 e^{-} \rightarrow \mathrm{Cu}$

and $2 \mathrm{H}^{+}+2 e^{-} \rightarrow \mathrm{H}_{2} \uparrow$

Hence, the cell diagram can be symbolized as,

$\mathrm{Zn}\left|\mathrm{Zn}^{2+}\right| \mathrm{H}^{+}, \mathrm{H}_{2}\left|\mathrm{Cu}^{2+}\right| \mathrm{Cu}$
From the visual observation of evolved gas as bubble, the physical test of the gas also claims that during electricity production $\mathrm{H}_{2}$ gas is generated as a by-product. Modification of electrode by electroplating the performance of the PKL cell is enhanced may be due to the increasing of surface area of electrode and the minimizing of local action. The coulombic efficiency data illustrate that this efficiency was lower comparing to other efficiencies may be the absence of salt bridge or separator between the electrodes [39-41]. However, the highest efficiency was obtained for $40 \%$ PKL sap with 5\% secondary salt in 55\% aqueous solution, which implies that the concentration of PKL juice can play an important role regarding efficiency. The large value of equilibrium constant revealed that the rate of forward electrochemical reaction was higher at higher concentration of oxidants. The presence of secondary salt $\left(5 \% \mathrm{CuSO}_{4} \cdot 5 \mathrm{H}_{2} \mathrm{O}\right)$ enhances the current and the potential. This may be due to the secondary salt effect, where the secondary salt increases the rate of dissociation of weak organic acids of PKL juice. 
Table 15 Observation of the energy efficiency variation with \% of PKL juice

\begin{tabular}{lll}
\hline Cell no. & \% of PKL juice & $\begin{array}{l}\text { Energy efficiency, } \\
\eta_{\mathrm{E}}(\%)=\frac{V I}{V I+I^{2} R} \times 100 \%\end{array}$ \\
\hline 1 & 60 & 97.43 \\
2 & 40 & 98.9 \\
3 & 40 & 99.96 \\
4 & 0 & 98.4 \\
5 & 50 & 97.12 \\
6 & 50 & 96.73 \\
\hline
\end{tabular}

\subsubsection{Results and discussion}

It is found from Tables 14 and 15 that the energy efficiency of the PKL cell is about $99.96 \%$. It may be noted here that this value of the efficiency is for the whole lifetime. Here, average of both current and voltage is taken. Therefore, efficiency will also change. If we want to measure the efficiency for a period of time, it is better to measure the power in ampere-hour (AH). Furthermore, Figs. 6, 7, 8, 9, 10,11 and 12 show the voltaic efficiency, charge transfer through the circuit and coulombic efficiency for different cells, respectively.

The effect of temperature on cell is basically the effect of temperature on electrolyte. In PKL cell, the electrolyte is the juice/extract of the PKL. Therefore, at lower temperature $\left(0^{\circ} \mathrm{C}\right)$, it becomes frozen. So, it is not possible to use this PKL cell at $0{ }^{\circ} \mathrm{C}$. At upper temperature, the organic properties of PKL juice/extract destroyed itself. So, it is not possible to use this cell in higher temperature. It is found the ideal temperature for this PKL system is room temperature, and it is found from 20 to $40^{\circ} \mathrm{C}$. But, it is also usable at a lower temperature from 5 to $60^{\circ} \mathrm{C}$ as other cells.

\section{Conclusions}

Finally, it can be concluded that PKL cell is:

- Less expensive.

- Highly efficient.

- Longer shelf-life.

- Environmentally friendly.

For these reasons, it introduces a sustainable platform to combat the power crisis of this world in future.

Acknowledgements The authors are grateful to the PKL electricity research group named Dr. M A Latif, Dr. Md. Sazzad Hossain, Dr.Fakrul Islam,Dr.Bapy Guh and Dr. Jesmin Sultana for their valuable suggestions and whole hearted cooperation during research work.
Funding This work is self funded.

\section{Compliance with ethical standards}

Conflict of interest On behalf of all the authors, the corresponding author declares that we do not have any conflict of interest.

\section{References}

1. Akter T, Bhuiyan MH, Khan KA, Khan MH (2017) Impact of photo electrode thickness and annealing temperature on natural dye sensitized solar cell. Published in the Journal of Elsevier. Ms. Ref. No.: SETA-D-16-00324R2

2. Guha B, Islam F, Khan KA (2018) Studies on redox equilibrium and electrode potentials. IJARIIE 4(4):1092-1102

3. Hamid MR (2013) Characterization of a battery cell fueled by Bryophyllum pinnatum sap. Int J Sci Eng Res 4(3):1-4

4. Hamid MR, Yusuf A, Wadud AMA, Rahaman MM (2016) Design and performance test of a prototype of a 12 volt dc battery fueled by Bryophyllum pinnatum Sap and improvement of its characteristics. Int J Electron Electr Eng 4(5):1-5

5. Haque MM, Ullah AKMA, Khan MNL, Kibria AKMFF, Khan KA (2018) Phyto-synthesis of $\mathrm{MnO}_{2}$ Nanoparticles for generating electricity. In: The international conference on physics-2018. Department of Physics, University of Dhaka, Dhaka, 1000, Bangladesh, Organizer-Bangladesh Physical Society (BPS), 08-10 March

6. Ali MR (2018) Solution of KdV and boussinesq using Darboux transformation. Commun Math Model Appl 3(3):16-27

7. Hasan M, Khan KA (2016) Bryophyllum pinnatum leaf fueled cell: an alternate way of supplying electricity at the off-grid areas in Bangladesh. In: Proceedings of 4th international conference on the developments in renewable energy technology [ICDRET 2016], p 01, 2016. https://doi.org/10.1109/ICDRET.2016.7421522

8. Hasan M, Khan KA (2018) Dynamic model of Bryophyllum pinnatum leaf fuelled BPL cell: a possible alternate source of electricity at the off-grid region in Bangladesh. Microsyst Technol. https:// doi.org/10.1007/s00542-018-4149-y

9. Hasan M, Khan KA (2018) Identification of BPL cell parameters to optimize the output performance for the off-grid electricity production. In: International conference on Physics-2018, Venue-Department of Physics, University of Dhaka, Dhaka, 1000, Bangladesh, Organizer-Bangladesh Physical Society (BPS), 08-10 March

10. Hasan M, Haque S, Khan KA (2016) An experimental study on the coulombic efficiency of Bryophyllum pinnatum leaf generated BPL cell. IJARIIE 2(1):1-9

11. Hasan MM, Khan MKA, Khan MNR, Islam MZ (2016) Sustainable electricity generation at the coastal areas and the islands of Bangladesh using biomass resources. City Univ J 02(01):09-13

12. Hasan M, Hassan L, Haque S, Rahman M, Khan KA (2017) A study to analyze the self-discharge characteristics of Bryophyllum pinnatum leaf fueled BPL test cell. IJRET 6(12):6-12

13. J.Sultana (2015) Electricity generation from Hybrid Bryophyllum pinnatum leaf and Solar photovoltaic system. Ph.D. dissertation, Dept. of Physics, University of Dhaka, Dhaka, Bangladesh. GRAND

14. Hasan L, Hasan M, Khan KA, Islam SMA (2018) SEM analysis of electrodes and measurement of ionic pressure by AAS data to identify and compare the characteristics between different biofuel based electrochemical cell. In: The international conference on physics-2018, Venue-Department of Physics, University of 
Dhaka, Dhaka-1000, Bangladesh, Organizer-Bangladesh Physical Society (BPS), 08-10 March

15. Hassan MM, Arif M, Khan KA (2018) Modification of germination and growth patterns of Basella alba seed by low pressure plasma. J Mod Phys. Paper ID: 7503531

16. Hossain MA, Khan MKA, Quayum ME (2017) Performance development of bio-voltaic cell from arum leaf extract electrolytes using $\mathrm{Zn} / \mathrm{cu}$ electrodes and investigation of their electrochemical performance. Int J Adv Sci Eng Technol 5(4):1-8

17. Islam F, Guha B, Khan KA (2018) Studies on pH of the PKL extract during electricity generation for day and night time collected Pathor Kuchi leaf. IJARIIE 4(4):1102-1113

18. Khan KA (1999) Technical note "copper oxide coatings for use in a linear solar Fresnel reflecting concentrating collector". J Renew Energy 17(4):603-608

19. Khan KA (2008) Inventors, electricity generation form Pathor Kuchi Leaf (PKL), Publication date 2008/12/31, Patent number BD 1004907

20. Khan MKA (2008) Studies on electricity generation from stone chips plant (Bryophyllum pinnatum). Int J Eng Tech 5(4):393-397

21. Khan KA (2009) Electricity generation form Pathor Kuchi Leaf (Bryophyllum pinnatum). Int J Sustain Agric Technol 5(4):146-152

22. Khan MKA (2018) An experimental observation of a PKL electrochemical cell from the power production view point. Presented as an invited speaker and abstract published in the Int conference on weather forecasting and advances in physics, 11-12 May 2018, Department of Physics, Khulna University of Engineering and Technology (KUET), Khulna, Bangladesh, pp 75

23. Khan KA, Alam MM (2010) Performance of PKL (Pathor Kuchi Leaf) electricity and its uses in Bangladesh. Int J Soc Dev Inf Syst $1(1): 15-20$

24. Khan KA, Arafat ME (2010) Development of portable PKL (Pathor Kuchi Leaf) Lantern. Int J Soc Dev Inf Syst 1(1):15-20

25. Khan KA, Bosu R (2010) Performance study on PKL electricity for using DC fan. Int J Soc Dev Inf Syst 1(1):27-30

26. Daily Electricity production in Germany in March (2018) [Online]. Available: https://www.energy-charts.de. Accessed 5 Mar 2018

27. Bangladesh Bureau of Statistics (BBS), Report on Bangladesh Sample Vital Statistics (2016) Available online, Accessed: 4 Mar 2018

28. Covington K et al (1985) Definition of pH scales, standard reference values, measurement of $\mathrm{pH}$ and related terminology (Recommendations 1984). Pure Appl Chem 57(3):531-542

29. Hill JW, Kolb DK (2001) Chemistry for changing times, 9th edn. Prentice Hall, Upper Saddle River

30. Khan KA, Hossain MI (2010) PKL electricity for switching on the television and radio. Int J Soc Dev Inf Syst 1(1):31-36

31. Luo $L(2019)$ New exact solutions of nonlinear $(3+1)$-dimensional Boiti-Leon-Manna-Pempinelli equation. Adv Math Phys 37(5):1-8

32. Ali MR, Hadhoud AR (2019) Application of Haar wavelet method for solving the nonlinear fuzzy integro-differential equations. J Comput Theor Nanosci 16(2):10-18

33. Ali MR, Hadhoud AR (2019) Solution of fractional Volterra-Fredholm integro-differential equations under mixed boundary conditions by using the HOBW method. Adv Differ Equ 2019:1-14

34. Khan KA, Paul S (2013) A analytical study on electrochemistry for PKL (Pathor Kuchi Leaf) electricity generation system. In: Publication date 2013/5/21, conference-energy tech, 2013 IEEE. publisher, IEEE, pp 1-6

35. Khan KA, Hossain A (2018) Off-grid 1 kW PKL power technology: design, fabrication, installation and operation. In: Proceedings of CCSN-2018, 27-28 October, 2018 at Kolkata, India

36. Khan MKA, Obaydullah AKM (2018) Construction and commercial use of PKL cell. IJARIIE 4(2):3563-3570
37. Khan KA, Rasel SR (2018) Prospects of renewable energy with respect to energy reserve in Bangladesh. IJARII 4(5):280-289

38. Khan KA, Rasel SR (2018) Studies on wave and tidal power extraction devices. Int J Adv Res Innov Ideas Educ 4(6):61-70

39. Khan KA, Yesmin F (2019) PKL electricity-a step forward in clean energy. Int J Adv Res Innov Ideas Educ 5(1):316-325

40. Khan KA, Paul S, Adibullah M, Alam MF, Sifat SM, Yousufe MR (2013) Performance analysis of BPL/PKL electricity module. Int J Sci Eng Res 4(3):1-4

41. Khan KA, Bhuyan MS, Mamun MA, Ibrahim M, Hassan L, Wadud MA (2018) Organic electricity from Zn/Cu-PKL electrochemical cell. Adv Intell Syst Comput. https://doi.org/10.1007/97898 1-13-1540-4

42. Khan KA, Bakshi MH, Mahmud AA (2014) Bryophyllum pinnatum leaf (BPL) is an eternal source of renewable electrical energy for future world. Am J Phys Chem 3(5):77-83. https:// doi.org/10.11648/j.ajpc.20140305.15

43. Khan KA, Alam MS, Mamun MA, Saime MA, Kamal MM (2016) Studies on electrochemistry for Pathor Kuchi leaf power system. J Agric Environ 12(1):37-42

44. Khan KA, Rahman A, Rahman MS, Tahsin A, Jubyer KM, Paul S (2016) Performance analysis of electrical parameters of PKL electricity (an experimental analysis on discharge rates, capacity and discharge time, pulse performance and cycle life and deep discharge of PathorKuchi Leaf (PKL) electricity cell). In: Innovative smart grid technologies-Asia (ISGT-Asia), 2016 IEEE. pp 540-544

45. Khan MKA, Paul S, Rahman MS, Kundu RK, Hasan MM, Moniruzzaman M, Al Mamun M (2016) A study of performance analysis of PKL electricity generation parameters: (an experimental analysis on voltage regulation, capacity and energy efficiency of pathor kuchi leaf (PKL) electricity cell). In: Power India international conference (PIICON), IEEE 7th. pp 1-6

46. Khan MKA, Rahman MS, Das T, Ahmed MN, Saha KN, Paul S (2017) Investigation on parameters performance of $\mathrm{Zn} / \mathrm{Cu}$ electrodes of PKL, AVL, tomato and lemon juice based electrochemical cells: a comparative study. In: Electrical information and communication technology (EICT), 2017 3rd international conference on. IEEE. IEEE, Khulna, Bangladesh, Bangladesh, pp 1-6. https://doi.org/10.1109/EICT2017.8275150

47. Khan KA, Ali MH, Mamun MA, Haque MM, Ullah AKMA, Khan MNI, Hassan L, Obaydullah AKM, Wadud MA (2018) Bioelectrical characteristics of $\mathrm{Zn} / \mathrm{Cu}-\mathrm{PKL}$ cell and production of nanoparticles (NPs) for practical utilization. In: 5th international conference on 'microelectronics, circuits and systems', Micro 2018, 19th and 20th May, 2018, In Association with: International Association of Science, Technology and Management. pp 59-66. http:// www.actsoft.org

48. Khan KA, Ali MH, Mamun MA, Ibrahim M, Obaidullah AKM, Hossain MA, Shahjahan M (2018) PKL electricity in mobile technology at the off-grid region. In: Published in the proceedings of CCSN-2018, 27-28 October, Kolkata, India, p 57

49. Khan KA, Ahmed SM, Akhter MM, Alam R, Hossen M (2018) Wave and tidal power generation. Int J Adv Res Innov Ideas Educ 4(6):71-82

50. Paul S, Khan KA, Islam KA, Islam B, Reza MA (2012) Modeling of a biomass energy based (BPL) generating power plant and its features in comparison with other generating plants. IPCBEE. https://doi.org/10.7763/IPCBEE.2012.V44.3

51. Khan KA, Paul S, Zobayer A, Hossain SS (2013) A Study on solar photovoltaic conversion. Int J Sci Eng Res 4(3):1-6

52. Khan KA, Hassan L, Obaydullah AKM, Islam SA, Mamun MA, Akter T, Hasan M, Alam M, Ibrahim M, Rahman MM, Shahjahan M (2018) Bioelectricity: a new approach to provide the electrical power from vegetative and fruits at off-grid region. J Microsyst Technol 24(3):2. https://doi.org/10.1007/s00542018-3808-3 
53. Khan KA, Hasan M, Islam MA, Alim MA, Asma U, Hassan L, Ali $\mathrm{MH}$ (2018) A study on conventional energy sources for power production. Int J Adv Res Innov Ideas Educ 4(4):214-228

54. Khan KA, Hossain MS, Kamal MM, Rahman MA, Miah I (2018) Pathor Kuchi leaf: importance in power production. IJARIIE 4(5):2395-2396

55. Khan KA, Hossain MA, Obaydullah AKM, Wadud MA (2018) PKL electrochemical cell and the Peukert's law. IJARIIE 4(2):4219-4227

56. Khan KA, Mamun MA, Ibrahim $M$, Hasan $M$, Ohiduzzaman $M$, Obaidullah AKM, Wadud MA, Shajahan M (2018) PKL electrochemical cell for off-grid areas: physics, chemistry and technology. In: Proceedings of CCSN-2018, at Kolkata, India

57. Khan KA, Manir SMM, Islam MS, Jahan S, Hassan L, Ali MH (2018) Studies on nonconventional energy sources for electricity generation. Int J Adv Res Innov Ideas Educ 4(4):229-244

58. Bangladesh Development Board (2018) Daily electricity generation report, 3rd March, 2018. Bangladesh Development Board. [Online] Available: www.bpdb.gov.bd
59. Orna MV, Stock J (1989) Electrochemistry, past and present. American Chemical Society, Columbus

60. Hasan M, Khan KA, Mamun MA (2017) An estimation of the extractable electrical energy from Bryophyllum pinnatum leaf. AIJRSTEM 01(19):100-106

61. Hasan M, Khan KA (2019) Experimental characterization and identification of cell parameters in a BPL electrochemical device. SN Appl Sci 1:1008. https://doi.org/10.1007/s4245 2-019-1045-8

62. Ali MR, Mousa MM, Ma WX (2019) Solution of nonlinear Volterra integral equations with weakly singular kernel by using the HOBW method. Adv Math Phys 5(4):1-10

Publisher's Note Springer Nature remains neutral with regard to jurisdictional claims in published maps and institutional affiliations. 